\title{
Teachers' And Students' Perceptions of Discipline and How Often Acts of Indiscipline Occur in Ghanaian Secondary Schools: Case Study of a Secondary School in Sunyani
}

\author{
Emmanuel Gyan ${ }^{1}$, Peter McCarthy ${ }^{2 *}$, Paul McCarthy ${ }^{1}$, Kwame Baah-Korang ${ }^{1}$ \\ ${ }^{1}$ Box 206 Department of General and Liberal Studies, Sunyani Polytechnic, Ghana \\ ${ }^{2}$ Mathematics Department, Lane College, 545 Lane Ave, Jackson, TN 38301, USA
}

\begin{abstract}
The study of teachers' and students' perceptions of discipline in a secondary school in Sunyani became necessary as a result of deviant behaviour of some students in Ghanaian secondary schools in recent times. Several measures have been taken by school authorities to curb this unruly behaviour of the students but to no avail. The study was designed to investigate teachers' and students' perceptions of discipline in secondary schools. Purposive sampling was used to sample 50 teachers who occupied various positions in the secondary school and 150 students comprising the Students Representative Council, class prefects and their secretaries. In all, 200 respondents were used for the study. A questionnaire was designed for the respondents. The main findings of the study were that both teachers and students of the school generally agreed on what constitute discipline, and also teachers and students admitted that eight out of the sixteen acts of indiscipline that were administered were found to occur most frequently in the school.
\end{abstract}

Keywords: Perceptions of discipline, Purposive sampling, and Students Representative Council.

\section{INTRODUCTION}

The assertion that discipline is the mother of all great achievements cannot be overemphasized in the field of education. Good discipline allows children to do their best in academic attainments. It also leads to the effective achievement of the goals of the school and the aspirations of the community. Schools are put up primarily to train students to become responsible adults so that they can conduct their affairs with dignity. However, this noble objective is being hampered by acts of indiscipline that of late have become a problem in Ghanaian secondary schools. A typical example was where two students from St. Peter's Secondary School were involved in armed robbery in which one of them was lynched (Hope, 1999). This and several other indiscipline cases occurring in some parts of the country prompted the then Deputy Director General of the Ghana Education Service to issue the following circular letter.

The Ghana Education Service and for that matter the Ministry of Education is concerned about the rising rate in recent times of incidents of violence and deviant behaviour among a section of students in public schools, thereby creating a feeling of insecurity and fear among students and teachers alike. These acts creeping into our society are foreign to our cherished culture and traditions as a nation and efforts must be made to stop them. (Ref. No. GES/DDG/ACAD/05, June 25, 1999)

Barely six months after the issuance of the above circular was a pistol retrieved from a student of Aggrey Memorial Zion Secondary School, Cape Coast (Quainoo, 1999). Again, a male student of Tamale Secondary School shot a female student in the same school with a gun (Alhassan, 2000). Perhaps the actions of the students may be due to the fact that they were at their adolescent stage of development whereby they begin to develop their personal attitudes towards what is right and what is wrong. The developments of personal attitudes are crucial in the maintenance of discipline in secondary schools, because it is at the adolescent stage when the students are reaching out for responsibility but are generally immature.

The level of indiscipline in Ghanaian Secondary Schools leaves much to be desired. It is in the recognition of this, that Dr. Kwame Addo Kuffour, Ghana's Minister of Defence stated that the declining rate of discipline in many schools has contributed to the erosion of high academic attainments, demoralized teaching staff and brought sorrow and disappointment to many parents(Frimpong, 2003). He observed that discipline is the mother of all great achievements in whatever field of endeavour and also emphasized respect for law, rules and regulations, self-control

*Corresponding Author:pmccarthy7651@gmail.com 
and desire to lead a life worthy of emulation. He said this at the $30^{\text {th }}$ Anniversary of Speech and Prize-Giving Day of Anglican Secondary School, Kumasi (Frimpong, 2003).The issue of students' indiscipline, at times, makes school administrators, teachers and parents feel uncomfortable.

\subsection{Statement of the Problem}

In Ghana, almost all the Secondary schools face disciplinary problems and this has been the concern of all and sundry. From the Disciplinary Committee file of the school, where the research was carried out, there have been many suspensions and withdrawals of students from the school. These suspensions and withdrawals have many repercussions on the affected students, the concerned parents, and the teachers, particularly those on the disciplinary committee. Again, the tone of the school is seriously at stake when students are found to be indiscipline and the community is not spared either. In view of the devastating consequences of disciplinary problems in Ghanaian schools, the call for the maintenance of sound discipline, which should be a partnership among the parents, the learners, the educators and the state cannot be overemphasized (Gyan, 2015).

\subsection{Purpose of the Study}

The study was done in order to find out whether teachers and students share common views on what constitutes discipline and also to know how often certain acts of indiscipline occur.

\subsection{Research Questions}

The study was guided by the following research questions.

- Do students and teachers agree on what constitute discipline?

- Do they (teachers and students) agree on how often certain acts of indiscipline occur in the school?

\subsection{Significance of the Study}

The study would assist the administrators of Secondary Schools to know what teachers and students perceive to be discipline in the school system. The knowledge about their perceptions on discipline would be a guide for taking disciplinary actions in other schools.

\subsection{Scope of the Study}

Although disciplinary problems prevail in all the secondary schools in Ghana, the study was carried out in a Secondary School in Sunyani because it is believed that teachers and students in Ghana have similar characteristics such as the qualification of teachers and general behaviour of students.

\subsection{Limitation}

The sample of the study was purposive and as such the finding may lack external validity. Therefore, the findings are not generalizable to all secondary schools in Ghana. Also, as seen from Table 2, though a greater percentage of teachers and students consider all the ten measures as very necessary, it must be pointed out, however, that these are not the only means of looking at discipline in schools; there might be several others that were not mentioned in this study. Therefore the study is limited to the factors mentioned on Table 2 only.

\subsection{Methodology}

The researcher purposively sampled 50 teachers and 150 students who were occupying the various positions that were directly involved in the disciplinary matters in the School for the study. Descriptive sample survey was considered to be a most appropriate method for the study. Babbie (1990) recommends the descriptive survey for the purpose of generalising from a sample to a population for inferences to be made about characteristics, attitudes or behaviour of the population. Gay (1987) also asserts that the descriptive survey involves collecting data in order to answer questions concerning the current status of the subject of the study. In view of the above assertions, a questionnaire was used to collect data from the sample in order to answer the research questions posed.

Frequency counts and percentages were employed to interpret the data in order to answer the research questions. Responses were compared to find out those that reflected the same opinion and vice versa.

\section{RESULTS AND DISCUSSIONS}

\subsection{Views on the Meaning of Discipline}

The word discipline has several meanings. However, five different meanings of discipline were provided for the respondents to express their views on them. Three options, strongly agree, agree and do not agree were given from 
American Research Journal of Humanities and Social Sciences, Volume 1, Issue 3, June 2015 ISSN 2378-7031

which the respondents were to indicate how they are in support of the definitions provided. The responses are provided in Table 1.

Table1. Responses on the Meaning of Discipline (percentage approximated to the nearest whole)

\begin{tabular}{|l|l|l|l|l|l|l|l|}
\hline Meaning of Discipline & \multirow{2}{*}{ Respondents } & \multicolumn{3}{l|}{ Strongly Agree } & Agree & \multicolumn{2}{l|}{ Do not agree } \\
\cline { 3 - 8 } & & No & $\%$ & No & $\%$ & No & $\%$ \\
\hline \multirow{2}{*}{ Orderliness } & Teachers & 40 & 80 & 10 & 20 & - & - \\
\cline { 2 - 8 } & Students & 96 & 64 & 49 & 33 & 5 & 3 \\
\hline \multirow{2}{*}{ Severe training } & Teachers & 5 & 10 & 19 & 38 & 26 & 52 \\
\cline { 2 - 8 } & Students & 50 & 33 & 61 & 41 & 39 & 26 \\
\hline \multirow{2}{*}{ Making children behave to instructions } & Teachers & 21 & 42 & 29 & 58 & - & - \\
\cline { 2 - 8 } & Students & 99 & 66 & 45 & 30 & 6 & 4 \\
\hline Control of Conduct & Teachers & 13 & 26 & 27 & 54 & 10 & 20 \\
\cline { 2 - 8 } & Students & 57 & 38 & 57 & 38 & 36 & 24 \\
\hline & Teachers & 27 & 54 & 21 & 42 & 2 & 4 \\
\cline { 2 - 8 } & Students & 73 & 49 & 71 & 47 & 6 & 4 \\
\hline
\end{tabular}

Source: field work, 2006

Orderliness being the first item on the Table 1, has an overwhelming majority of $80 \%$ and $64 \%$ of the teachers and the students respectively expressing their strong agreement with that concept of discipline. On that same issue $20 \%$ of the teachers and about $33 \%$ of the students said they agreed with the school of thought that says that discipline means orderliness. However, no teacher said he or she did not agree and only about $3 \%$ of the students said they disagreed. These high percentages of both teachers and students suggest that there is some element of orderliness among the teachers and students in the School. Even though there is some level of disagreement between the teachers and students on the issue of orderliness, the percentage may be considered as negligible since it is only $3 \%$. It is therefore believed that both the teachers and students to a greater extent do agree that discipline means orderliness. Perhaps the $3 \%$ of the students who said they did not agree are the type of students who do not want to comport themselves in any way. The views of the majority of the respondents confirm the claim of Musaazi (1982) that a disciplined person is orderly.

The next item on Table 1 states that discipline means severe training. On this issue, both the teachers and the students have divergent views. On the part of the students while about 33\% representing a third of the student respondents said they strongly agreed that discipline means severe training, about $41 \%$ on the other hand said they agreed and $26 \%$ of them said they did not agree. From the view point of the teachers $52 \%$ of them said they did not agree that discipline means severe training, while 38\% of them said they were in agreement with that. Only $10 \%$ said they strongly agree. Perhaps while majority of the teachers are thinking of a laissez-fair type of discipline, the greater percentage of students are also thinking otherwise and that they are expecting the teachers to subject them to severe training as it prevails in the military. The views of the majority of the students are in support of definition of discipline as given by Catherine, George, Anne and Virginia (1988) which says that discipline is an instrument of severe training as indicated earlier in the literature review.

The third item on the meaning of discipline is making children behave to instructions. While $42 \%$ of the teachers said they strongly agree to this definition, majority of the students representing $66 \%$ also shared a similar view. Also $58 \%$ of the teachers said they agree and $30 \%$ of the students also supported this view. However, no teacher and only $4 \%$ of the students said they disagreed. This indicates that both the teachers and the students agreed to a greater extent that making children behave to instructions forms discipline and this confirms the claims made by Charles (1981) that discipline means making children toe the line and Asiedu-Akrofi (1978) who sees discipline as externally imposed sanctions where students are always compelled to obey their teachers.

The next concept of discipline is punishments and rewards. As many as 57 students representing $38 \%$ said they strongly agree that discipline involves punishments and rewards. Again, 38\% also agreed. On their part, 26\% and $54 \%$ of the teachers said that they strongly agree and agree respectively that discipline involves punishments and rewards. Only $24 \%$ of the students and $20 \%$ of the teachers said they do not agree that discipline involves punishments and rewards. In the view of Tamakloe et al (1996) external discipline involves external restriction and restrain on a person by an outside agency through punishments and rewards which the result also confirms that.

Control of conduct being the last item on Table 1 was strongly agreed by about $49 \%$ and $54 \%$ of the students and teachers respectively. As many as 71 students and 21 teachers representing about $47 \%$ and $42 \%$ respectively did say 


\section{American Research Journal of Humanities and Social Sciences, Volume 1, Issue 3, June 2015}

ISSN 2378-7031

that they agree with school of thought who says that discipline involves control of conduct. Interestingly, only $4 \%$ of the teachers and $4 \%$ of the students said they do not agree that discipline involves control of conduct. The information confirms the definition of discipline from the Penguin Dictionary of Psychology (1985) which states that discipline is the control of conduct either of subordinates by a superior or of one's own conducts.

A careful look at the Table 1 again reveals that respondents agreed on four out of the five items on what constitute discipline. These are: orderliness, punishments and rewards, making children behave to instructions and control of conduct. The percentage differences between that of the teachers and the students who disagreed on the four items listed above are not very significant. However, their views on item two seem to vary greatly. More than half of the teachers representing 52\% disagreed with the view that discipline means severe training. On the contrary, about $74 \%$ of the students were in support of the school of thought who says that discipline means severe training and $48 \%$ of the teachers also shared a similar view. Despite these differences, on the whole, it can be concluded that teachers and students in the school generally agreed on what discipline means.

\subsection{Views on How Often Acts of Indiscipline Occur}

There are several acts of indiscipline that take place in the School but sixteen of these acts of indiscipline were used to find out from the teachers and the students how often they do occur in the school. The responses and their corresponding percentages are provided in Table 2.

Table2. Responses on how Often Acts of Indiscipline Occur (percentage approximated to the nearest whole)

\begin{tabular}{|c|c|c|c|c|c|c|c|c|c|}
\hline \multirow[t]{2}{*}{ Acts of indiscipline } & \multirow[t]{2}{*}{ Respondents } & \multicolumn{2}{|c|}{\begin{tabular}{|l|} 
Very often \\
\end{tabular}} & \multicolumn{2}{|c|}{ Often } & \multicolumn{2}{|c|}{ Seldom } & \multicolumn{2}{|c|}{ Never } \\
\hline & & No. & $\%$ & No. & $\%$ & No. & $\%$ & No. & $\%$ \\
\hline \multirow[t]{2}{*}{ Students late to school. } & Teachers & 34 & 68 & 12 & 24 & 4 & 8 & - & - \\
\hline & Students & 104 & 69 & 42 & 28 & 4 & 3 & - & - \\
\hline \multirow[t]{2}{*}{ Teachers' late to school. } & Teachers & - & - & 2 & 4 & 38 & 76 & 10 & 20 \\
\hline & Students & - & - & 23 & 15 & 102 & 68 & 25 & 17 \\
\hline \multirow[t]{2}{*}{ Bullying of juniors. } & Teachers & 4 & 8 & 28 & 56 & 18 & 36 & - & - \\
\hline & Students & 24 & 16 & 39 & 26 & 87 & 58 & - & - \\
\hline \multirow[t]{2}{*}{ Lying to teachers. } & Teachers & 6 & 12 & 38 & 76 & 6 & 12 & - & - \\
\hline & Students & 24 & 16 & 42 & 28 & 84 & 56 & - & - \\
\hline \multirow[t]{2}{*}{ Students' Absenteeism. } & Teachers & 8 & 16 & 14 & 28 & 28 & 56 & - & - \\
\hline & Students & 41 & 27 & 66 & 44 & 43 & 29 & - & \\
\hline \multirow[t]{2}{*}{ Teachers' absenteeism. } & Teachers & - & - & - & - & 50 & 100 & - & - \\
\hline & Students & - & - & 27 & 18 & 114 & 76 & 9 & 6 \\
\hline \multirow[t]{2}{*}{ Breaking of bounds. } & Teachers & 8 & 16 & 30 & 60 & 12 & 24 & - & - \\
\hline & Students & 66 & 44 & 56 & 37 & 28 & 19 & - & - \\
\hline \multirow[t]{2}{*}{ Littering of the school. } & Teachers & 8 & 16 & 34 & 68 & 8 & 16 & - & \\
\hline & Students & 60 & 40 & 48 & 32 & 42 & 28 & - & \\
\hline \multirow[t]{2}{*}{ Sexual misconduct. } & Teachers & 2 & 4 & 12 & 24 & 32 & 64 & 4 & 8 \\
\hline & Students & 22 & 15 & 26 & 17 & 92 & 61 & 10 & 7 \\
\hline \multirow[t]{2}{*}{ Improper dressing. } & Teachers & 12 & 24 & 18 & 36 & 20 & 40 & - & - \\
\hline & Students & 30 & 20 & 63 & 42 & 57 & 38 & - & - \\
\hline \multirow[t]{2}{*}{ Cheating in examinations. } & Teachers & 6 & 12 & 18 & 36 & 26 & 52 & - & - \\
\hline & \begin{tabular}{|l|} 
Students \\
\end{tabular} & 22 & 15 & 51 & 34 & 77 & 51 & - & - \\
\hline \multirow[t]{2}{*}{ Students' demonstrations. } & Teachers & - & - & - & - & 14 & 28 & 36 & 72 \\
\hline & Students & - & - & - & - & 45 & 30 & 105 & 70 \\
\hline \multirow[t]{2}{*}{ Stealing other student's items. } & Teachers & 6 & 12 & 30 & 60 & 14 & 28 & - & - \\
\hline & Students & 78 & 52 & 42 & 28 & 30 & 20 & - & - \\
\hline \multirow[t]{2}{*}{ Alcoholism and smoking. } & Teachers & 2 & 4 & 8 & 16 & 40 & 80 & - & - \\
\hline & Students & 27 & 18 & 57 & 38 & 66 & 44 & - & - \\
\hline \multirow[t]{2}{*}{ Students not attending prep. } & Teachers & - & - & 20 & 40 & 30 & 60 & - & - \\
\hline & \begin{tabular}{|l} 
Students \\
\end{tabular} & 27 & 18 & 56 & 37 & 67 & 45 & - & - \\
\hline \multirow{2}{*}{$\begin{array}{l}\text { Disrespect } \\
\text { fulness }\end{array}$} & Teachers & 4 & 8 & 20 & 40 & 26 & 52 & - & - \\
\hline & Students & 42 & 28 & 54 & 36 & 54 & 36 & - & - \\
\hline
\end{tabular}


American Research Journal of Humanities and Social Sciences, Volume 1, Issue 3, June 2015 ISSN 2378-7031

Source: field work, 2006

The first item on Table 2 is students reporting late to school when school reopens. About $68 \%$ of the teachers and $69 \%$ of the students said that act of indiscipline occurs very often in the school. Only $8 \%$ of the teachers and $3 \%$ of the student respondents said students seldom report late when school reopens. The reasons for students reporting late when school reopens could be either the parents find it difficult to settle the school fees or it may be due to truancy. This suggests that actual academic work of the school is likely to begin a bit late whenever school reopens. The results confirm the assertion made by Adentwi (1998) that absenteeism and lateness are some of the disciplinary problems in schools.

On the question of teachers reporting late when school reopens, only $4 \%$ of the teachers and $15 \%$ of the students viewed it to be often in the school. However, about $76 \%$ of the teachers and $68 \%$ of the students agreed that teachers in the School seldom report late when school reopens. As many as $20 \%$ of the teachers and $17 \%$ of the students said teachers in the School never report late when school reopens. The reason for punctuality of teachers may be attributed to devotion and commitment to their work.

Bullying is the third item on Table 2. Both the teachers and students agreed that there is some bullying in the school but the rate at which it takes place is perceived differently. A careful look at Table 2 shows that $64 \%$ of the teachers admitted that bullying often takes place in the school and this was supported by $26 \%$ of the students. However, 58\% of the students as against $36 \%$ of the teachers said bullying seldom occurs in the school. Interestingly, none of the teachers as well as the students said bullying does not take place in the School. This actually confirms the findings of Olweus (1987) that 15\% of school children are involved in bully-victim problems. He added that one in ten students is regularly harassed by bullies. The reason for bullying in schools is that once it was done to them it must be done to others too- as compensate to themselves.

Another act of indiscipline which attracted divergent views is item four on Table 2 which is students lying to teachers. Whereas $76 \%$ of the teachers agreed that students often lie to teachers only $26 \%$ of the students shared a similar view with the teachers. Students' unfaithfulness was found to be one of the serious problems to teachers. Research conducted by Schrupp and Gjerde (1953) also attests to this fact. On the other hand, 56\% of the students and $12 \%$ of the teachers said students' dishonesty seldom occurs in the school. Perhaps, what the teachers consider as a lie the students may perceive it differently. It could also be that the students did not want to tell the truth that they have been lying to the teachers. The cause of students lying may be that they are not bold enough to face the consequences of their own actions.

The next act of indiscipline on Table 2 is students' absenteeism. About $28 \%$ of the teachers and $44 \%$ of the students said students' absenteeism is quite often in the school. The remaining $56 \%$ of the teachers and $29 \%$ of the students said students' absenteeism in the School is rare. This shows that the students in the School like cutting classes which confirms the findings of Greene (1962). Among his findings was that class cutting ranked fifth out of nine acts of indiscipline listed. Students normally absent themselves due to poor teaching methods, lack of interest in the subject matter and truancy.

On the issue of teachers' absenteeism, it is interesting to know that $100 \%$ of the teachers and $76 \%$ of the students were of the opinion that teachers rarely absent themselves from classes. The high percentages of teachers and students suggest that there is a possibility of proper supervision and monitoring of teachers attendance in the School. Students breaking bounds comes next on Table 2 . About $44 \%$ of the students said students very often break bounds and $60 \%$ of the teachers said that act of indiscipline often goes on in the school. This proves Goodlad (1984) right when he said that students breaking of bounds disrupt school discipline. Students break bounds if there are too many restrictions in the school or they run away just for merry making.

The next item on Table 2 is the littering of compound and classrooms. About $68 \%$ of the teachers said the students often litter the school while $40 \%$ of the students said that littering of the school is very often. Also $24 \%$ of the teachers and $28 \%$ of the students admitted that littering seldom goes on in the school. From this analysis we can infer that the compound and the classrooms are most of the time filthy and precious time must be spent on cleaning. The cause for littering may be that the culture of putting litter into a bin has not been inculcated in them.

Sexual misconduct being the ninth item on Table had $64 \%$ of the teachers and $61 \%$ of the students saying that sexual misconduct rarely occurs in the school. Whereas $24 \%$ of the teachers said that sexual misconduct often takes place in the school, only $17 \%$ of the students shared a similar view. The above statistics shows that sexual misconduct takes place in the school but the rate is not very alarming as indicated by Millman, Schaefer and Cohen (1980). They 
claim that one of the major disciplinary problems in educational institutions is sexual misbehaviour. Lack of proper sex education may lead to sexual misconduct. Again peer pressure is also a possible cause of sexual misconduct.

As regards the issue of improper dressing by the students, $24 \%$ of the teachers and $20 \%$ of the students said it occurs very often in the school. Another $36 \%$ of the teachers and $42 \%$ of the students said students often dress improperly in the school. Again, $40 \%$ and $38 \%$ of the teachers and students respectively were of the view that students seldom dress improperly in the school. This shows that both the teachers and students have observed the issue of improper dressing in the school. Improper dressing of the students may be due to the absence of code of dressing in the school. The school must try and have a code of dressing in order to curtail this act of indiscipline.

On the question of examination malpractices, more than half of the teachers and the students were of the opinion that examination malpractices seldom occur in the school. About $52 \%$ of the teachers and $51 \%$ of the students responded to that. The rest, $36 \%$ and $34 \%$ of the teachers and students respectively shared a similar view that examination malpractices often occur in the school. The possible cause for examination malpractices is that students normally do not prepare adequately for the examination.

Regarding students' demonstrations, an overwhelming majority of the teachers and students, $72 \%$ and $70 \%$ respectively shared the view that students' demonstrations never take place in the school. The remaining $28 \%$ and $30 \%$ of the teachers and students respectively said students' demonstrations seldom take place in the school. This contradicts the assertion made by Goodlad (1984) that one worry of school administrators, teachers and parents is students' demonstrations. The results suggest that the school authorities seek the welfare of the students. A credit must be given to both the students and the school administration for not experiencing students' riots.

Stealing of students' items by some other students is also another source of worry for both the teachers and students in the School. About $60 \%$ of the teachers said this act of indiscipline often occurs in the school and $52 \%$ of the students agreed that theft cases in their various dormitories and classrooms are very often. This goes to prove why three students were sacked from the school in 1999 for stealing as indicated earlier in chapter one page six of this study. Students normally steal due to envy and bad company.

Drinking of alcohol and smoking of marijuana is the last but two items on Table 2. A careful look at it reveals that $38 \%$ of the students were of the opinion that students often indulge themselves in drinking and smoking. This view was supported by only $16 \%$ of the teachers. The vast difference in percentages may be due to the fact that most of the teachers do not see the students when they are drunk but the other students do because they are in the same dormitories with them. About $80 \%$ of the teachers and $44 \%$ of the students did indicate that students rarely smoke and take in alcohol. Smoking and drinking of alcohol are greatly influenced by peers, bad company, fun and curiosity. This confirms the findings of Adentwi (1998) which indicate that disciplinary problems in schools due to self-comportment behaviour include smoking, drunkenness and improper dressing.

The fifteenth item on Table 2 is Students not attending prep studies. From the table, $40 \%$ of the teachers as well as $37 \%$ of the students shared the view that students often do not go for prep studies. However, the remaining $60 \%$ of the teachers and $45 \%$ of the students said students seldom go for prep studies. Perhaps there is no proper supervision for prep studies therefore the students choose not to go for the prep studies. The final item on Table 2 is students' disobedience. About $36 \%$ of the students and $40 \%$ of the teachers said students are often disrespectful. Another $36 \%$ and $52 \%$ of the students and teachers respectively said students' rarely show disobedience. This proves the assertion made by Greene (1962) that when teachers of Senior-High-Schools were asked to list students misbehaviour in order of frequency, disobedience placed second.

The data on Table 2 reveals that eight out of sixteen acts of indiscipline listed very often occur in the school. These eight acts of indiscipline include students reporting late when school reopens, bullying of juniors, students lying to teachers, and students' absenteeism. The rest are breaking of bounds by the students, littering of classrooms and compound, improper dressing and some students stealing other students' items. Item twelve on Table 2 which is students' demonstrations had a majority of the respondents saying that it rarely occurs in the school. The remaining seven acts of indiscipline that seldom occur in the school are: teachers' lateness to school when school reopens, teachers' absenteeism, sexual misconduct, cheating in examinations. The rest include students' alcoholism and smoking.

\section{CONCLUSION}

The findings indicate that respondents agreed on what constituted discipline. It can therefore be generalised that teachers and students of the School share similar ideas on what constitute discipline. The respondents said that 
discipline means: orderliness, making children behave to instructions, control of conduct and punishments and rewards. Suffice it to say that when ideal disciplinary measures are being taken both the teachers and the students must surely embrace them.

The results of the study also show that respondents shared similar views on how often an act of indiscipline occurs. Eight out of the sixteen acts of indiscipline that were administered were found to occur most frequently in the school. These include students reporting late when school reopens, bullying of junior students, lying to teachers and students' absenteeism. The rest are breaking of bounds by the students, littering of school compound and classrooms, improper dressing and some students stealing other students' items. The acts of indiscipline that rarely occur include teachers reporting late when school reopens, students breaking bounds to drink alcohol and smoke marijuana outside campus, students not attending prep, cheating in examinations, sexual misconduct, teachers' absenteeism and students' disobedience. Students' demonstration which is the twelfth item on the acts of indiscipline was found to be the only act that the majority of the respondents said it does not occur in the school.

The eight acts of indiscipline that frequently occur in the school at higher rates should be given due attention they deserve as they may lead to total breakdown of discipline in the school. The remaining seven acts that occur but at a lower rate must be nipped in the bud.

\section{REFERENCES}

[1] Adentwi, K. I. (1998). Teachers' and students' perceptions of classroom indiscipline in selected Senior Secondary Schools in the Cape Coast Municipality. Unpublished M.Phil Thesis, University of Cape Coast, Cape Coast.

[2] Alhassan, Z. (2000, May 31). Shooting drama at school. Daily Graphic (No. 47922), p.1.

[3] Asiedu-Akrofi, K. (1978). School organisation in modern Africa. Tema: Ghana Publishing Corporation.

[4] Babbie, E. (1990). Survey research methods (2nd ed.). New Delhi: Prentice Hall of India Private Ltd.

[5] Catherine, S., George, D., Anne, S. \& Virginia, T. (1988) Chambers English Dictionary(ED). New York: Cambridge University Press.

[6] Charles, C. M. (1981). Building classroom discipline: From models to practice. New York: Longman Inc.

[7] Frimpong, D. E. (2003, July 21). Kumasi Anglican gets government fund. Daily Graphic (No.148877), p. 20.

[8] Gay, L. R. (1987). Educational research: Competencies for analysis and application (3rded.) Columbus, Ohio: Merrill Publication Company.

[9] Goodlad, J. (1984). A place called school. New York: McGraw-Hill Publishing Co.

[10] Greene, J. E. (1962). Alleged misbehaviours among senior high school sudents. Journal of social psychology, 58, $371-382$.

[11] Hope, K. E. (1999, June 7). Student lynched after robbing forex bureau at gunpoint. Ghanaian Times (No. 12956), p. 1.

[12] Millman, H. L., Schaefer, C. E. \& Cohen, J. J. (1980). Therapies for school behaviour problems: A handbook for practical interventions. San Francisco: Jossey-Bass Publishers.

[13] Musaazi, J. C. (1982). The theory and practice of educational administration. London: Macmillan Publishers Ltd.

[14] Olweus, D. (1987). School yard bullying intervention Cambridge, MA: Blackwell Hillsdale, NJ: Erlbaum.

[15] Quainoo, J. (1999, Dec. 17). Pistol found in boys' hostel. Daily Graphic (No.147784), p.1.

[16] Schrupp, M. H. \& Gjerde, C. M. (1953). Teacher growth in attitude toward behaviour problems of children. Journal of educational psychology, 44, 203-214.

[17] Tamakloe, E. K., Atta, E. T. \& Amedahe F. K. (1996). Principles and methods of teaching. Accra: Black Mask Ltd. 